\title{
Factors Affecting Motivation for Career Selection of Public Accountants
}

Budiandru Budiandru

Accounting Departement, Faculty of Economics and Business, Universitas Muhammadiyah Prof.

Dr.Hamka

Jl. Tanah Merdeka No.20, Rambutan, Kec. Ps Rebo, East Jakarta, DKI Jakarta, Indonesia

E-mail: budiandru@uhamka.ac.id

* Corresponding Author

\begin{abstract}
The purpose of this study was to determine the effect of intrinsic value, work environment, and labor market considerations on the motivation to choose a career as a public accountant. This research method uses multiple linear regression analysis with a sample of 210 students of the Faculty of Economics and Business Prof. Dr. Hamka. The results showed that the intrinsic value of work had a positive and significant effect on the motivation to choose a career to become a public accountant, while the work environment and job market considerations did not affect. The research's strength and uniqueness focus on a particular sample, namely students from 2016 to 2018. In that period, students were able to compile financial reports according to general accounting standards in Indonesia and internationally and understand auditing best practices to have the decision to have a career as a public accountant. The research results also contribute to developing insights, references, understanding, and knowledge about the driving factors in choosing a public accountant career. Public accounting firms need to consider workspace and freedom for auditors to complete existing work, providing intellectual challenges with a dynamic work atmosphere.
\end{abstract}

Keywords: Motivation; Intrinsic Intrinsic Value; Environment; Job Market; Accountants Public Accountants

Article History: Received: November 122020 Accepted: February 222021 Published: April 52021

Buadianru, B.(2021). Factor Affecting Motivation for Career Selection of Public Accountants. Akrual: Jurnal Akuntansi (JA), 12(2): 204-216. DOI: https://doi.org/10.26740/jaj.v12n2.p204-216

\section{INTRODUCTION}

Every student certainly wants to have a good and promising career for his future (Heyneman \& Lee, 2016). To obtain this career, students are expected to motivate themselves to get the career they aspire to (Batool \& Ghayas, 2020). Career choice is a process or individual activity in business prepare to enter a job-related career through a series of directed and systematic activity processes to choose a career as desired (Kossek \& Ollier-Malaterre, 2020; Sullivan \& Al Ariss, 2019). In making a career choice, someone was first looking for various alternative professions (Ong \& Theseira, 2016). The business world's development must be responded to by the quality of accounting education and ready to use in work (Apostolou, Dorminey, \& Hassell, 2020).

Self-motivation aims to improve and develop the quality of work they have to face the world of work that is getting tougher and full of competition (Alnıaçı, Alnıaçık, Akçin, \& Erat, 2012; Raziq \& Maulabakhsh, 2015). Accounting is one of the majors in economics, which is in great demand by students today. The average student chooses to major in accounting, driven by their desire to become accounting professionals (Enget, Garcia, \& Webinger, 2020). Besides, they are also motivated by assuming that accountants 
will need accountants by many organizations and companies (Hiebl, 2018; Oboh \& Ajibolade, 2017).

Public accounting is much needed and is also seen as having bright prospects for the world of work because this profession provides an invaluable intellectual challenge and learning experience (Catchpowle \& Smyth, 2016; Sugahara \& Boland, 2014). This profession also provides the opportunity to find a challenging and varied job because it can be assigned in various places and various companies with different characteristics and conditions (Inceoglu, Selenko, McDowall, \& Schlachter, 2019; Inegbedion, Inegbedion, Peter, \& Harry, 2020). The public accounting profession can be one of the most expensive professions because the largest income source from public accountants has shifted from audit services to management consulting services (Laksmi \& Al Hafis, 2019; Pincus, Stout, Sorensen, Stocks, \& Lawson, 2017).

The intrinsic value of the job and financial rewards are essential aspects of the public accounting profession (Adekoya, Oboh, \& Oyewumi, 2020). Public accountants are needed to reduce information asymmetry between the principal (owner), the agent (professional manager), and the debtor (Hope, 2013; Xia \& Zhu, 2009). The current development of the public accounting profession is in line with the need for a larger number of public accountants; however, the development of public accountants in Indonesia is slower than in other ASEAN countries.

Table 1. Comparison of the Number of Public Accountants in ASEAN (2019)

\begin{tabular}{ccccccccc}
\hline \multirow{2}{*}{ Country } & \multirow{2}{*}{ Population } & Accountant & \multicolumn{6}{c}{ Number of Public Accountants } \\
\cline { 4 - 9 } & & Organization & 2014 & 2015 & 2016 & 2017 & 2018 & 2019 \\
\hline Brunei & 4 Million & BICPA & 58 & 56 & 122 & 233 & 259 & 284 \\
Cambodia & 15 Million & KICPAA & 263 & 291 & 274 & 246 & 254 & 248 \\
Indonesia & 251 Million & IAI & 18,507 & 26,782 & 28,110 & 29,982 & 28,761 & 27,985 \\
Laos & 2 Million & LICPAA & 176 & 101 & 107 & 186 & 217 & 209 \\
Malaysia & 29 Million & MIA & 31,454 & 32,511 & 33,398 & 34,549 & 35,507 & 36,178 \\
Myanmar & 55 Million & MICPA & 595 & 738 & 998 & 1,157 & 1,157 & 1,351 \\
Philippines & 105 Million & PICPA & 21,586 & 19,380 & 10,528 & 31,495 & 39,716 & 18,866 \\
Singapore & 5 Million & ISCA & 28,530 & 29,839 & 32,153 & 32,054 & 32,419 & 32,643 \\
Thailand & 67 Million & TFAC & 63,619 & 68,777 & 71,128 & 77,505 & 79,258 & 85,258 \\
Vietnam & 92 Million & VAA & 8,000 & 9,800 & 8,000 & 8,000 & 8,000 & 10,000 \\
\hline
\end{tabular}

Source : ASEAN Federation of Accountants, Annual Report (2019)

From table 1, it can be seen that the number of accountants in Indonesia is currently still relatively small compared to the total population of Indonesia, which is 251 million, Indonesia only has 27,985 accountants in 2019. Indonesia lacks a number of public accountants and still needs this profession in large numbers, in anticipation of a growing business sector. This shows the lack of the interest of young people to enter the public accounting profession. Even though the number of companies in Indonesia that need to be audited is increasing, it can be concluded that students' interest in a career as a public accountant is low. This can be influenced by economic motivation, labor market motivation, work environment, social values, and many other factors.

Technology, globalization, new business relationships, and a multidisciplinary economic environment have transformed the accounting profession (Baskerville \& Hay, 
2010; Hopper, Lassou, \& Soobaroyen, 2017). Any of these changes can impact those who choose to major in accounting and factors that influence their choice of jobs in the field (Garkaz, Banimahd, \& Esmaeili, 2011; Omar, Zakaria, Ismail, Sin, \& Selvakumar, 2015). The auditing profession is essential, given the integral and evolving role of internal and external auditors in ensuring an accurate description of its financial position and compliance with applicable regulations (Omolaye \& Jacob, 2018; Parker \& Johnson, 2017). Indeed, the accounting profession's persistent challenge is recruiting high-quality employees suitable for jobs in the accounting field (Donaldson \& Walsh, 2015; Kyriacou, 2016).

Career selection is a process of choosing a position influenced by psychological, sociological, cultural, geographic, educational, physical, economic, and open opportunities that together form one's position (Akosah-Twumasi, Emeto, Lindsay, Tsey, \& MalauAduli, 2018; Cascio \& Montealegre, 2016). This person acquires several beliefs, values of needs, abilities, skills, interests, personality traits, understanding, and knowledge, all of which lead to behavior patterns aligned with society and culture's expectations (Ertosun \& Adiguzel, 2018; Narkabilova, 2020).

Intrinsic work is the satisfaction that individuals receive during or after work (Raza, Akhtar, Husnain, \& Akhtar, 2015). These factors include rewards, opportunities for promotion, job responsibilities, intellectual challenges, and training (Osborne \& Hammoud, 2017; Yang, Luo, Sun, Lu, \& Kang, 2018). The intrinsic factor of work has a relationship with the individual's satisfaction when or after he has done the job. The intrinsic factor is inseparable from the work's nature and provides immediate satisfaction when done.

A work environment is a place where a production process is carried out (creating added value for goods/services), including all the equipment used (hardware), systems, software that support these activities, and other environments that are affected by it and the people who interact in it (Agrawal \& Rahman, 2015; Reinartz, Wiegand, \& Imschloss, 2019). The nature of the job, the level of competition, and the amount of pressure are factors of the work environment. The work environment is considered in choosing a profession, especially like routine work and work that can be completed quickly.

Labor market considerations are considered by someone in choosing a job because every job has different opportunities and opportunities (Ong \& Theseira, 2016). Professions that have a broad job market will be more desirable than professions with a smaller job market. Labor market considerations include job security, availability of employment opportunities, and easy access to job vacancies.

Fajarsari (2020) shows that career motivation and social motivation have a significant positive effect on accounting students' interest in attending accounting profession education. Sapariyah et al. (2020) show that financial rewards, training, professional recognition, and job market considerations significantly influence public accountants' career choices. Murdiawati (2020) revealed that financial rewards, job market considerations, professional training, professional recognition, social values, and work environment significantly affect choosing a career to become a public accountant.

Dewi and Yasa (2020) found that career motivation, self-efficacy, and job market considerations significantly affect accounting students' interest in taking the CPA exam. Dippa et al. (2020) reveal that professional recognition, social values, employment, and work considerations positively affect accounting students' interest to become public 
accountants. Suharti and Irman (2020) show that financial rewards, professional training, social values, professional recognition, and work environment significantly affect career choices as public accountants.

Arif et al. (2020) state that the public accounting profession's perception, motivation, and adversity intelligence significantly affect becoming a public accountant. Aditya and Hasibuan (2020) show that student perception variables, gender, and personality type have a positive and significant influence on career choice as a public accountant. Fadrul and Nifia (2019) show that social values, family demands, financial rewards, and the work environment influence the accounting profession's choice. Warsitasari and Astika (2017) state that career motivation, economic motivation, perceptions, and job market considerations positively affect career choice as a public accountant.

$\mathrm{H}_{1} \quad$ : The intrinsic value of work has a positive effect on choosing a career to become a public accountant.

$\mathrm{H}_{2}$ : The work environment has a positive effect on the motivation to choose a career as a public accountant.

$\mathrm{H}_{3} \quad$ : Labor market considerations have a positive effect on the motivation to choose a career as a public accountant.

$\mathrm{H}_{4}$ : The intrinsic value of work, work environment, and market considerations simultaneously positively affect the motivation to choose a career to become a public accountant.

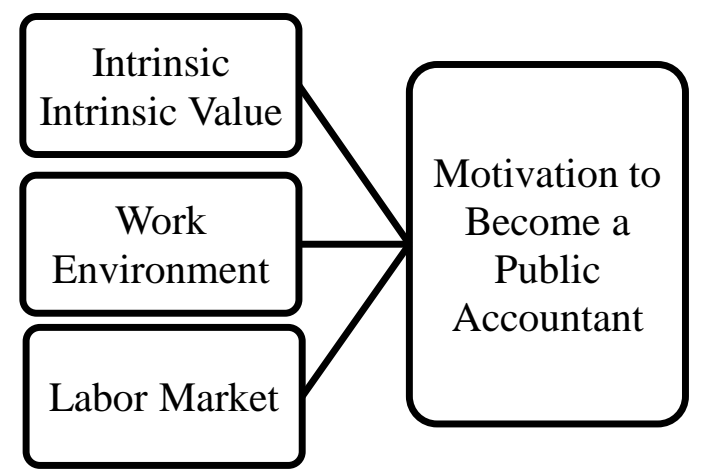

Figure 1. Research Model

Motivating factors for choosing a career to become a public accountant include job market considerations (Dewi \& Yasa, 2020; Murdiawati, 2020; Suharti \& Irman, 2020; Warsitasari \& Astika, 2017), professional recognition and financial awards (Dippa, Mendra, \& Bhegawati, 2020; Murdiawati, 2020; Sapariyah, Putri, \& Fujianto, 2020; Suharti \& Irman, 2020; Warsitasari \& Astika, 2017), work environment (Dippa et al., 2020; Saputra, 2018; Suharti \& Irman, 2020), professional training (Murdiawati, 2020; Sapariyah et al., 2020; Suharti \& Irman, 2020), social values (Dippa et al., 2020; Fadrul \& Nifia, 2019; Murdiawati, 2020; Suharti \& Irman, 2020), work environment (Fadrul \& Nifia, 2019; Murdiawati, 2020; Suharti \& Irman, 2020), perception (Aditya \& Hasibuan, 2020; Fajarsari, 2020; Warsitasari \& Astika, 2017), gender (Aditya \& Hasibuan, 2020; Dewi \& Yasa, 2020; Saputra, 2018), personality types (Aditya \& Hasibuan, 2020), and 
motivation (Arif, Askandar, \& Mahsuni, 2020; Dewi \& Yasa, 2020; Fajarsari, 2020; Saputra, 2018; Warsitasari \& Astika, 2017).

The existence of a phenomenon related to the minimal number of public accounting professions in Indonesia makes researchers interested in reexamining the factors that influence accounting students to become public accountants by considering aspects of the instrument's value, work environment, and market considerations. The difference in this research lies in the case study conducted at the University of Prof. Dr. Hamka Jakarta and the intrinsic value variable. First, this study contributes to providing information about the factors that influence motivation to become a public accountant. Information about the factors that influence becoming a public accountant is essential for accounting firms because accounting firms will recruit graduates. Second, considerations in decision making. Decision making is vital for graduates in choosing careers as public accountants who are thought to be influential in choosing careers. Third, references to support further research on the influence of motivation. The research results will be useful for similar research.

\section{RESEARCH METHOD}

This study's population was students of the economics and business faculty, University of Muhammadiyah Prof. Dr. Hamka. The sample in this study were students majoring in accounting, class 2016-2018. The sampling technique used was the purposive sampling method by selecting samples based on predetermined criteria (characteristics), namely accounting students from at least 5 to 8 semesters. The reason for choosing this sample was that students this semester were considered to have sufficient knowledge and are deemed to have already planned to choose the career they want after graduation.

The data used in this study uses primary data obtained directly through a questionnaire with closed questions. Data collection is obtained from questionnaire answers from strongly disagree to agree strongly. The respondents' questionnaire is used to determine the effect of intrinsic value (INV), work environment (WRE), and job market (JBM) considerations on the motivation (MV) to choose a career as a public accountant. After getting the respondent's data, the next step is to test the validity and reliability. Validity and reliability testing aims to test whether the questionnaire distributed to obtain research data is valid and reliable or not. This research uses tools and materials, including the first questionnaire, which functions to get data from respondents with the help of google form, distributed via online media. Second, after the data was collected, the data was tested using multiple linear regression analysis to answer the research objectives using a Statistical Package tool for the Social Sciences (SPSS).

$$
M V=\beta_{0}+\beta_{1} I N V_{1}+\beta_{2} W R E_{2}+\beta_{3} J B M_{3}+\varepsilon
$$

\section{RESULTS AND DISCUSSION}

Data collection was carried out after distributing questionnaires to 270 respondents from each batch of 90 questionnaires. From the results of the distribution of the questionnaires, as many as 210 questionnaires $(77.78 \%$ ) percent could be used, 57 questionnaires did not return $(21.11 \%)$, and three questionnaires were incomplete $(1.11 \%)$. 
Table 2. Questionnaire category

\begin{tabular}{ccc}
\hline Category & Total & Percentage (\%) \\
\hline The questionnaire was not returned & 57 & 21.11 \\
Incomplete questionnaire & 3 & 1.11 \\
Questionnaires that can be used & 210 & 77.78 \\
\hline Total & 270 & 100
\end{tabular}

The validity test and reliability test results show that the data are valid and reliable, as evidenced by the validity test with the pearson correlation ranging from 0.000 to 0.012 , where the value is less than the significance level of 0.05 . In comparison, the reliability test with Cronbach's Alpha gets a value of 0.614, where the value is more significant than $r_{\text {table }}$ 0.1161 .
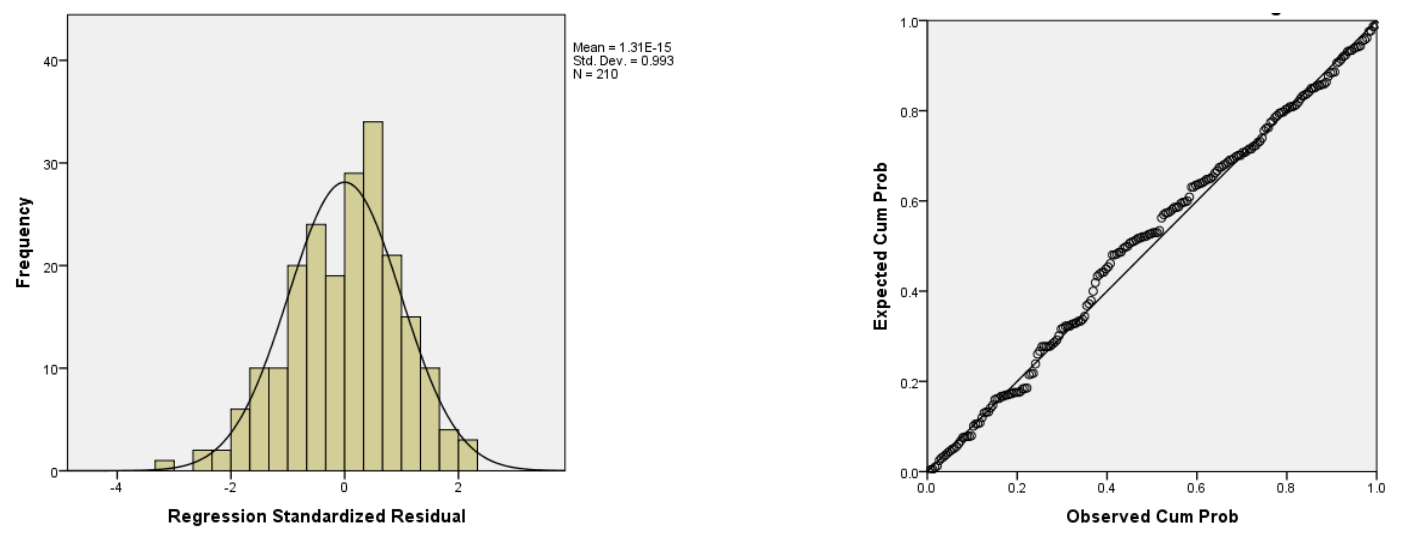

Figure 2. Histogram Graph and P-Plot

The normality test aims to test whether there is a correlation between confounding errors or not in a linear regression model. Based on the test results using a histogram graph where the histogram graph provides a distribution pattern that deviates to the left, which means that the data is normally distributed. Furthermore, in the P-Plot image, it can be seen that the points spread to follow and approach the diagonal line so that it can be concluded that they meet the assumption of normality. Data normality testing was also carried out using the Kolmogorov-Smirnov, where the Asymp value. Sig. (2-tailed) is greater than the alpha value of $5 \%$, so that it can be concluded that the data is normally distributed.

Table 3. One-Sample Kolmogorov-Smirnov Test

\begin{tabular}{llc}
\hline & & Unstandardized Residual \\
\hline $\mathrm{N}$ & & 210 \\
Normal Parameters ${ }^{\mathrm{b}}$ & Mean & $0 \mathrm{E}-7$ \\
& Std. Deviation & 2.00877636 \\
Most Extreme Differences & Absolute & .071 \\
& Positive & .04 \\
& Negative & -.071 \\
Kolmogorov-Smirnov Z & & 1.026 \\
Asymp. Sig. (2-tailed) & & .243 \\
\hline
\end{tabular}


The multicollinearity test is conducted to determine whether there is a linear relationship deviation between the regression model's independent variables. This multicollinearity test uses tolerance and VIF values. The test results show that the variables of intrinsic value, work environment, and market considerations have a tolerance value of more than 0.10 and a VIF value of less than 0.1 so that all variables are free from multicollinearity problems.

Table 4. Multicollinearity and Heteroscedasticity Test Results

\begin{tabular}{cccc}
\hline \multirow{2}{*}{ Model } & \multicolumn{2}{c}{ Collinearity Statistics } & \multirow{2}{*}{ Sig. } \\
\cline { 2 - 3 } & Tolerance & VIF & \\
\hline INV & .862 & 1.16 & .981 \\
WRE & .864 & 1.157 & .252 \\
JBM & .969 & 1.032 & .583 \\
\hline
\end{tabular}

The heteroscedasticity test is used to determine whether there is an inequality of variants of the residuals for all regression models' observations. The glacier test results show that all tested variables are more significant than 5\%, so it can be concluded that the data is free from heteroscedasticity problems.

Table 5. Autocorrelation Test Results

\begin{tabular}{lc}
\hline & Unstandardized Residual \\
\hline Test Value & .14323 \\
Cases < Test Value & 105 \\
Cases $\geq$ Test Value & 105 \\
Total Cases & 210 \\
Number of Runs & 101 \\
Z & -.692 \\
Asymp. Sig. (2-tailed) & .489 \\
\hline
\end{tabular}

The autocorrelation test is carried out to determine whether there is a correlation between the prediction model variables and time changes. Therefore, if the assumption of autocorrelation occurs in a prediction model, the disturbance value is no longer paired independently but is paired in autocorrelation. The runs test results showed that the Asymp Sig (2-tailed) value was more significant than $5 \%$, so it can be concluded that the data is free from autocorrelation problems.

The estimation results of the multiple linear regression equation are obtained:

$$
M V=11.331+.862 I N V_{1}+.864 W R E_{2}+.969 J B M_{3}+\varepsilon
$$

A constant value of 11,331 indicates that if the intrinsic value (INV), work environment (WRE), and labor market considerations (JBM) are zero, the motivation for choosing a career as a public accountant (MV) is worth 11.331. The INV variable's regression coefficient is .8621 , meaning that if other independent variables are fixed in value and INV increases by 1 unit, the MV will increase by .8621 units. The regression coefficient for the WRE variable is .864 , meaning that if other independent variables are 
fixed in value and WRE has increased by 1 unit, the MV will increase by .864 units. The regression coefficient for the JBM variable is .969, meaning that if the other independent variables have a fixed value and the JBM has increased by 1 unit, the MV will increase by .969 units.

Tabel 6. Multiple Linear Regression Results

\begin{tabular}{cccccc}
\hline \multirow{2}{*}{ Model } & \multicolumn{2}{c}{ Unstandardized Coefficients } & Standardized Coefficients & \multirow{2}{*}{ S } & \multirow{2}{*}{ Sig. } \\
\cline { 2 - 4 } & $\mathrm{B}$ & Std. Error & Beta & & \\
\hline (Constant) & 11.331 & 2.534 & & 4.471 & .000 \\
INV & .862 & 1.16 & .241 & 3.332 & .001 \\
WRE & .864 & 1.157 & .042 & .584 & .560 \\
JBM & .969 & 1.032 & .016 & .233 & .816 \\
\hline
\end{tabular}

The partial test results (t-test) show that the intrinsic value (INV) has a significant effect on the motivation to choose a career as a public accountant (MV), while the work environment variable (WRE) and job market considerations (JBM) do not affect. While simultaneously, all the variables tested have a significant effect on the motivation to choose a career as a public accountant (MV) $\left(F_{\text {count }} 5.010>F_{\text {table }} 2.729\right)$. The $F$ test serves to analyze the effect of all independent variables together on the dependent variable. The $\mathrm{F}$ test results will be beneficial for a built model, whether the model is significant or not. If the model is significant, the model can be used to predict or predict future conditions.

The intrinsic value of work is the satisfaction in a person during or after work, which is caused by factors of appreciation, opportunities for promotion, job responsibilities, intellectual challenges, and training (Osborne \& Hammoud, 2017; Yang et al., 2018). The intrinsic factor cannot be separated from the work's nature and provides immediate satisfaction when the job is done (Sugahara \& Boland, 2014). Job satisfaction is the emotional attitude of someone who is fun and loves his job (Ong \& Theseira, 2016). This attitude is reflected in work morale, discipline, and work performance (Nolder \& Kadous, 2018). The accountant profession is one of the professions that prioritize factors in the intrinsic value of work (Raza et al., 2015). This is following the Theory of Reasoned Action (TRA) model, where according to this theory, a person's behavior is influenced by one's intention to act, and the intention is determined by attitude and subjective norms (Law, 2010). The intrinsic value is tested as a component that reflects the career choice attitude as a public accountant. So in this study, the intrinsic value variable is considered in line with this theory.

The work environment is also one of the factors that can be considered for someone in determining their career choices, but in this case, the results do not affect. The work environment is the same as the work atmosphere, such as routine, attractive work, and frequent overtime (Murdiawati, 2020; Raziq \& Maulabakhsh, 2015). Also, the level of competition among employees and work pressure are factors of the work environment (Fadrul \& Nifia, 2019). A career as a public accountant can be categorized as a more attractive and challenging job (Senjari, Hasan, \& Sofyan, 2016). Labor market considerations are closely related to jobs that can be accessed in the future (Murdiawati, 2020). Jobs that have a broader job market will be more desirable than jobs with a small job market (Pincus et al., 2017). Job market considerations can be a reason or a factor for a 
person in determining his career (Ong \& Theseira, 2016). Thus, labor market considerations are a factor that can influence accounting students to determine their career as public accountants, but in this case, the results do not affect. Students who become respondents still think that the accounting profession is not a flexible job. The accountant profession is not a flexible job, as seen from respondents' low average score for the statement items on the labor market consideration variables.

The public accounting profession has a significant role in supporting the economic development of a country, namely recognizing economic development so that it is more effective and efficient with the power of transparency. Besides, public accountants' role is also to improve the quality and credibility of financial information or financial reports of an entity. Therefore, the Indonesian state must increase transparency and accountability in the financial presentation.Public accountants are needed to reduce information asymmetry between the principal (owner), the agent (professional manager), and the debtor. The agent has more information than the principal or creditor, which results in the agent acting in his favor which is not part of the principal's wishes.

There are many opportunities for the public accountant profession in the future because the only profession is authorized by the Ministry of Finance of the Republic of Indonesia to provide audit services, the enactment of the Limited Liability Company Law, the banking sector which requires its customers to obtain a certain amount of credit facilities and the number of facilities provided to them. Public Accountant to provide professional services. It is no less important than the number of public accountants in Indonesia is not proportional to the number of users of the public accounting profession. A tough challenge facing the public accounting profession in Indonesia than other Association of Southeast Asian Nations (ASEAN) countries is the relatively few college graduates who intend to become public accountants. Of course, it will be a tough challenge to enter foreign public accountants into Indonesia so that the competition will be tighter.

\section{CONCLUSION}

Based on the discussion that has been done, this study concludes that based on the partial test (t-test), it shows that the intrinsic value of work affects the motivation to choose a career to become a public accountant, while other variables do not affect. Furthermore, based on the simultaneous test, it shows that the variables of intrinsic value of work, work environment, and labor market considerations significantly affect the motivation to choose a career to become a public accountant.

Students who choose a career as a public accountant agree that intrinsic value provides intellectual challenges, a dynamic work atmosphere, demands creativity and gives freedom to complete essential tasks to be taken into consideration. The work of public accountants is considered to contain intrinsic value elements, which are expected by students so that they can develop more. Public accounting firms need to consider space and freedom for auditors to complete existing workspace, providing intellectual challenges with a dynamic work atmosphere to avoid boredom to improve skills.

The public accounting profession will face challenges in the future. First, the structure of public accountants in Indonesia who are over 50 years old reaches $67 \%$. Second, the public accounting profession seems to be no longer attractive, indicated by the changing profession of public accountants. Third, it is not the primary choice of accounting students for a career. Fourth, Indonesian public accountants have no readiness to face the 
global market era, marked by a lack of mastery of foreign languages. Fifth, the development of the public accounting profession in Indonesia is low compared to other ASEAN countries.

This study only focuses on the research scope at one university, so further research can be considered by adding research scope by taking samples of accounting students from several universities, both private and state universities. Further research can also add independent variables that influence motivation to become a public accountant, such as professional recognition, personality, and career flexibility.

\section{REFERENCES}

Adekoya, A. C., Oboh, C. S., \& Oyewumi, O. R. (2020). Accountants Perception of the Factors Influencing Auditors' ethical Behaviour in Nigeria. Heliyon, 6(6), 1-8. https://doi.org/10.1016/j.heliyon.2020.e04271

Aditya, M. R., \& Hasibuan, A. B. (2020). Pengaruh Persepsi, Gender dan Tipe Kepribadian Mahasiswa Terhadap Pemilihan Karir Mahasiswa Akuntansi sebagai Akuntan Publik (Studi Kasus pada Mahasiswa Akuntansi Universitas Darma Persada). WACANA EKONOMI (Jurnal Ekonomi, Bisnis Dan Akuntansi), 19(1), 4357. https://doi.org/10.22225/we.19.1.1579.43-57

Agrawal, A. K., \& Rahman, Z. (2015). Roles and Resource Contributions of Customers in Value Co-creation. International Strategic Management Review (Vol. 3). Holy Spirit University of Kaslik. https://doi.org/10.1016/j.ism.2015.03.001

Akosah-Twumasi, P., Emeto, T. I., Lindsay, D., Tsey, K., \& Malau-Aduli, B. S. (2018). A Systematic Review of Factors That Influence Youths Career Choices-the Role of Culture. Frontiers in Education, 3(58), 1-15. https://doi.org/10.3389/feduc.2018.00058

Alnıaçık, Ü., Alnıçıı, E., Akçin, K., \& Erat, S. (2012). Relationships Between Career Motivation, Affective Commitment and Job Satisfaction. Procedia - Social and Behavioral Sciences, 58, 355-362. https://doi.org/10.1016/j.sbspro.2012.09.1011

Apostolou, B., Dorminey, J. W., \& Hassell, J. M. (2020). Accounting Education Literature Review. Journal of Accounting Education, 51, 1-24. https://doi.org/10.1016/j.jaccedu.2020.100670

Arif, M. F., Askandar, N. S., \& Mahsuni, A. W. (2020). Analisis Pengaruh Persepsi Profesi Akuntan Publik, Motivasi Dan Kecerdasan Adversity Mahasiswa Universitas Islam Malang Terhadap Minat Menjadi Akuntan Publik. E-Jra, 9(1), 60-74.

Baskerville, R. F., \& Hay, D. (2010). The Impact of Globalization on Professional Accounting Firms: Evidence from New Zealand. Accounting History, 15(3), 285308. https://doi.org/10.1177/1032373210367669

Batool, S. S., \& Ghayas, S. (2020). Process of Career Identity Formation Among Adolescents: Components and Factors. Heliyon, 6(9), 1-9. https://doi.org/10.1016/j.heliyon.2020.e04905

Cascio, W. F., \& Montealegre, R. (2016). How Technology Is Changing Work and Organizations. Annual Review of Organizational Psychology and Organizational Behavior, 3, 349-375. https://doi.org/10.1146/annurev-orgpsych-041015-062352

Catchpowle, L., \& Smyth, S. (2016). Accounting and Social Movements: An Exploration of Critical Accounting Praxis. Accounting Forum, 40(3), 220-234. https://doi.org/10.1016/j.accfor.2016.05.001 
Dewi, I. G. A. A. O., \& Yasa, K. D. (2020). Motivasi , Gender , Self Efficacy dan Pertimbangan Pasar Kerja Terhadap Minat Mahasiswa untuk Mengikuti Ujian CPA Test Center. Jurnal Ilmiah Akuntansi Dan Bisnis, 5(1), 103-115.

Dippa, F. A. T., Mendra, N. P. Y., \& Bhegawati, D. A. S. (2020). Faktor-faktor yang Mempengaruhi Minat Mahasiswa Akuntansi untuk Berkarir menjadi Akuntan Publik. Jurnal Kharisma, 2(1), 113-124.

Donaldson, T., \& Walsh, J. P. (2015). Research in Organizational Behavior Toward a theory of Business. Research in Organizational Behavior, 35, 181-207. https://doi.org/10.1016/j.riob.2015.10.002

Enget, K., Garcia, J. L., \& Webinger, M. (2020). Majoring in Accounting: Effects of Gender, Difficulty, Career Opportunities, and the Impostor Phenomenon on Student Choice. Journal of Accounting Education, 53, 1-10. https://doi.org/10.1016/j.jaccedu.2020.100693

Ertosun, O. G., \& Adiguzel, Z. (2018). Leadership, Personal Values and Organizational Culture. Contributions to Management Science. https://doi.org/10.1007/978-3-319$77622-4 \_3$

Fadrul, \& Nifia. (2019). Analisis Faktor-Faktor yang Mempengaruhi Minat Mahasiswa Akuntansi terhadap Profesi Akuntan. Jurnal Ilmiah Akuntansi, 3(2), 175-187.

Fajarsari, H. (2020). Pengaruh Motivasi dan Persepsi Terhadap Minat Mahasiswa Mengikuti Pendidikan Profesi Akuntansi (PPAK) di Kota Semarang. Pamator Journal, 13(1), 30-43. https://doi.org/10.21107/pamator.v13i1.7001

Garkaz, M., Banimahd, B., \& Esmaeili, H. (2011). Factors Affecting Accounting Students' Performance: The Case of Students at the Islamic Azad University. Procedia - Social and Behavioral Sciences, 29, 122-128. https://doi.org/10.1016/j.sbspro.2011.11.216

Heyneman, S. P., \& Lee, B. (2016). International Organizations and the Future of Education Assistance. International Journal of Educational Development, 48, 9-22. https://doi.org/10.1016/j.ijedudev.2015.11.009

Hiebl, M. R. W. (2018). Management Accounting as a Political Resource for Enabling Embedded Agency. Management Accounting Research, 38, 22-38. https://doi.org/10.1016/j.mar.2017.03.003

Hope, O. K. (2013). Large Shareholders and Accounting Research. China Journal of Accounting Research, 6(1), 3-20. https://doi.org/10.1016/j.cjar.2012.12.002

Hopper, T., Lassou, P., \& Soobaroyen, T. (2017). Globalisation, Accounting and Developing Countries. Critical Perspectives on Accounting, 43, 125-148. https://doi.org/10.1016/j.cpa.2016.06.003

Inceoglu, I., Selenko, E., McDowall, A., \& Schlachter, S. (2019). (How) Do Work Placements Work? Scrutinizing the Quantitative Evidence for a theory-driven Future Research Agenda. Journal of Vocational Behavior, 110, 317-337. https://doi.org/10.1016/j.jvb.2018.09.002

Inegbedion, H., Inegbedion, E., Peter, A., \& Harry, L. (2020). Perception of Workload Balance and Employee job Satisfaction in Work Organisations. Heliyon, 6(1), 1-9. https://doi.org/10.1016/j.heliyon.2020.e03160

Kossek, E. E., \& Ollier-Malaterre, A. (2020). Desperately Seeking Sustainable Careers: Redesigning Professional Jobs for the Collaborative Crafting of Reduced-load work. Journal of Vocational Behavior, 117(May 2018), 1-15. https://doi.org/10.1016/j.jvb.2019.06.003 
Kyriacou, O. (2016). Accounting for Images of 'equality' in Digital Space: Towards an Exploration of the Greek Accounting Professional Institute. Critical Perspectives on Accounting, 35, 35-57.

Laksmi, A. C., \& Al Hafis, S. I. (2019). The Influence of Accounting Students' Perception of Public Accounting Profession: A Study from Indonesia. Journal of Contemporary Accounting, 1(1), 47-63. https://doi.org/10.20885/jca.vol1.iss1.art5

Law, P. K. (2010). A Theory of Reasoned Action Model of Accounting Students' Career Choice in Public Accounting Practices in the Post-Enron. Journal of Applied Accounting Research, 11(1), 58-73. https://doi.org/10.1108/09675421011050036

Murdiawati, D. (2020). Faktor-Faktor Yang Mempengaruhi Minat Mahasiswa Akuntansi Di Surabaya Untuk Memilih Karir Menjadi Akuntan Publik. Jurnal Akuntansi Dan Pajak, 20(2), 248-256. https://doi.org/10.29040/jap.v20i2.748

Narkabilova, G. (2020). The Culture of Communication as the Basic of Personality. Journal of Critical Reviews, 7(5), 812-815. https://doi.org/10.31838/jcr.07.05.167

Nolder, C. J., \& Kadous, K. (2018). Grounding the Professional Skepticism Construct in Mindset and Attitude Theory: A way Forward. Accounting, Organizations and Society, 67, 1-14. https://doi.org/10.1016/j.aos.2018.03.010

Oboh, C. S., \& Ajibolade, S. O. (2017). Strategic Management Accounting and Decision Making: A Survey of the Nigerian Banks. Future Business Journal, 3(2), 119-137. https://doi.org/10.1016/j.fbj.2017.05.004

Omar, M. K., Zakaria, A., Ismail, S., Sin, J. S. L., \& Selvakumar, V. (2015). Job Selection Preferences of Accounting Students in Malaysian Private Universities. Procedia Economics and Finance, 31(15), 91-100. https://doi.org/10.1016/s22125671(15)01135-1

Omolaye, K. E., \& Jacob, R. B. (2018). The Role of Internal Auditing In Enhancing Good Corporate Governance Practice in an Organization. International Journal of Accounting Research, 6(1), 1-8. https://doi.org/10.4172/2472-114x.1000174

Ong, Q., \& Theseira, W. (2016). Does Choosing Jobs Based on Income Risk Lead to Higher Job Satisfaction in the Long Run? Evidence from the Natural Experiment of German Reunification. Journal of Behavioral and Experimental Economics, 65, 95108. https://doi.org/10.1016/j.socec.2016.08.003

Osborne, S., \& Hammoud, M. S. (2017). Effective Employee Engagement in the Workplace. International Journal of Applied Management and Technology, 16(1), 50-67. https://doi.org/10.5590/ijamt.2017.16.1.04

Parker, S., \& Johnson, L. A. (2017). The Development of Internal Auditing as a Profession in the U.S. During the Twentieth Century. Accounting Historians Journal, 44(2), 4767.

Pincus, K. V., Stout, D. E., Sorensen, J. E., Stocks, K. D., \& Lawson, R. A. (2017). Forces for Change in Higher Education and Implications for the Accounting Academy. Journal of Accounting Education, 40, 1-18. https://doi.org/10.1016/j.jaccedu.2017.06.001

Raza, M. Y., Akhtar, M. W., Husnain, M., \& Akhtar, M. S. (2015). The Impact of Intrinsic Motivation on Employee's Job Satisfaction. Management and Organizational Studies, 2(3), 80-88. https://doi.org/10.5430/mos.v2n3p80

Raziq, A., \& Maulabakhsh, R. (2015). Impact of Working Environment on Job Satisfaction. Procedia Economics and Finance, 23, 717-725. 
https://doi.org/10.1016/s2212-5671(15)00524-9

Reinartz, W., Wiegand, N., \& Imschloss, M. (2019). The Impact of Digital Transformation on the Retailing Value Chain. International Journal of Research in Marketing, 36(3), 350-366. https://doi.org/10.1016/j.ijresmar.2018.12.002

Sapariyah, R. A., Putri, I. S., \& Fujianto, R. L. (2020). Pengaruh Penghargaan Finansial, Pelatihan Profesional, Pengakuan Profesional, dan Pertimbangan Pasar Kerja Terhadap Pemilihan Karir Akuntan Publik Pada Mahasiswa Akuntansi di Perguruan Tinggi Surakarta. Financial : Jurnal Akuntansi, 6(1), 98-104.

Saputra, A. J. (2018). Pengaruh Persepsi Mahasiswa Akan Minat, Motivasi, Pelatihan Profesional, Gender Dan Lingkungan Pekerjaan Terhadap Pilihan Karir Akuntan Publik Dan Non Publik. Jurnal Riset Akuntansi Mercu Buana, 4(2), 126. https://doi.org/10.26486/jramb.v4i2.478

Senjari, R., Hasan, A., \& Sofyan, A. (2016). Pengaruh Motivasi, Lingkungan Kerja Dan Nilai Sosial Terhadap Minat Mahasiswa Akuntansi Dalam Memilih Karir Sebagai Akuntan Publik. Jurnal Online Mahasiswa Fakultas Ekonomi Universitas Riau, 3(1), 133-147.

Sugahara, S., \& Boland, G. (2014). How Accounting Students Define Success, and the Factors Affecting their Success and Failure, While Studying in the Accounting Schools of Japan. Procedia - Social and Behavioral Sciences, 141, 64-69. https://doi.org/10.1016/j.sbspro.2014.05.012

Suharti, \& Irman, A. P. (2020). Analisis Faktor-Faktor yang Mempengaruhi Pemilihan Karir Sebagai Akuntan Publik. Kurs : Jurnal Akuntansi, Kewirausahaan Dan Bisnis, 5(1), 85-101.

Sullivan, S. E., \& Al Ariss, A. (2019). Making Sense of Different Perspectives on Career Transitions: A Review and Agenda for Future Research. Human Resource Management Review, 1-17. https://doi.org/10.1016/j.hrmr.2019.100727

Warsitasari, I. A. T. S., \& Astika, I. B. P. (2017). Pengaruh Motivasi, Persepsi, Penghargaan Finansial, Pasar Kerja dan Pengakuan Profesional Pada Pemilihan Karir Akuntan Publik. E-Jurnal Akuntansi, 21(3), 2222-2252. https://doi.org/10.24843/EJA.2017.v21.i03.p19

Xia, D., \& Zhu, S. (2009). Corporate Governance and Accounting Conservatism in China. China Journal of Accounting Research, 2(2), 81-108. https://doi.org/10.1016/s17553091(13)60015-5

Yang, B., Luo, Y., Sun, Y., Lu, W., \& Kang, L. (2018). Simulation and Experimental Research on Magnetic Circuit of MRF Yield Stress Testing Device. Journal of Failure Analysis and Prevention, 18(5), 1286-1292. https://doi.org/10.1007/s11668018-0520-7 